\title{
"Has Nigerian agricultural output spurred economic growth: the financing gap model using stepwise regression"
}

\begin{tabular}{|c|c|}
\hline AUTHORS & $\begin{array}{l}\text { Funso Abiodun Okunlola } \\
\text { Godswill Osagie Osuma (Dttps://orcid.org/0000-0001-9242-5265 } \\
\text { Alexander Ehimare Omankhanlen (D https://orcid.org/0000-0002-4004-4046 }\end{array}$ \\
\hline ARTICLE INFO & $\begin{array}{l}\text { Funso Abiodun Okunlola, Godswill Osagie Osuma and Alexander Ehimare } \\
\text { Omankhanlen (2019). Has Nigerian agricultural output spurred economic growth: } \\
\text { the financing gap model using stepwise regression. Investment Management and } \\
\text { Financial Innovations, } 16(3), 157-166 \text {. doi:10.21511/imfi.16(3).2019.15 }\end{array}$ \\
\hline DOI & http://dx.doi.org/10.21511/imfi.16(3).2019.15 \\
\hline RELEASED ON & Thursday, 05 September 2019 \\
\hline RECEIVED ON & Sunday, 26 May 2019 \\
\hline ACCEPTED ON & Monday, 24 June 2019 \\
\hline LICENSE & $\begin{array}{l}(\mathrm{cc}) \mathrm{EY} \\
\text { This work is licensed under a Creative Commons Attribution } 4.0 \text { International } \\
\text { License }\end{array}$ \\
\hline JOURNAL & "Investment Management and Financial Innovations" \\
\hline ISSN PRINT & $1810-4967$ \\
\hline ISSN ONLINE & $1812-9358$ \\
\hline PUBLISHER & LLC "Consulting Publishing Company "Business Perspectives" \\
\hline FOUNDER & LLC "Consulting Publishing Company "Business Perspectives" \\
\hline
\end{tabular}

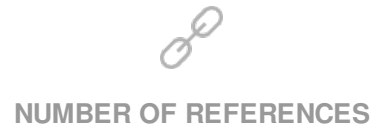

28

\section{NUMBER OF FIGURES}

0
$-=-$
$-=-$

NUMBER OF TABLES

6

(C) The author(s) 2022. This publication is an open access article. 


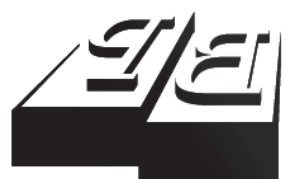

BUSINESS PERSPECTIVES

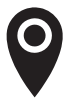

LLC "CPC "Business Perspectives" Hryhorii Skovoroda lane, 10, Sumy, 40022, Ukraine

www.businessperspectives.org

Received on: $26^{\text {th }}$ of May, 2019 Accepted on: $24^{\text {th }}$ of June, 2019

(C) Funso Abiodun Okunlola, Godswill Osagie Osuma, Ehimare Alexander Omankhanlen, 2019

Funso Abiodun Okunlola, Ph.D. Student, Department of Banking and Finance, Covenant University, Nigeria.

Godswill Osagie Osuma, Assistant Lecturer, Department of Banking and Finance, Covenant University, Nigeria.

Ehimare Alexander Omankhanlen, Senior Lecturer, Department of Banking and Finance, Covenant University, Nigeria.

\section{(c) (i)}

This is an Open Access article, distributed under the terms of the Creative Commons Attribution 4.0 International license, which permits unrestricted re-use, distribution, and reproduction in any medium provided the original work is properly cited.
Funso Abiodun Okunlola (Nigeria), Godswill Osagie Osuma (Nigeria), Ehimare Alexander Omankhanlen (Nigeria)

\section{HAS NIGERIAN AGRICULTURAL OUTPUT SPURRED ECONOMIC GROWTH: THE FINANCING GAP MODEL USING STEPWISE REGRESSION}

\begin{abstract}
This study examined if the Nigerian agricultural output has spurred economic growth and the best fit agricultural financing gap model for growing the economy. The study explored the dynamics of different technicality approach that stepwise regression has to offer. From the seven baskets of predictors - agricultural guaranteed finance to oil palm, cocoa, groundnuts, fishery, poultry, cattle, roots and tubers - the step fitted three predictors: roots and tubers, cocoa and poultry based on "a b" parameter with the highest "t-stats" and significant p-value and subsequently executed the model using stepwise regression analysis with the help of Statistical Package for Social Sciences (SPSS) version 23. The dataset covers a thirty-six year period from 1981 to 2017. The source of the data is from the Central Bank of Nigeria 2018 statistical bulletin. The findings showed that individually, root and tubers has the most contributory impact on economic growth with 81 percent. Jointly followed is cocoa at 87 percent and poultry at 90 percent. The study thus recommends a comparative cost advantage to financing agriculture with the most impactful contribution to economic growth based on the model.
\end{abstract}

Keywords

agriculture, finance, economic growth, stepwise regression, agricultural products

JEL Classification Q1, Q14, O47

\section{INTRODUCTION}

It is popular parlance that Rome was not built in a day. The reason they say a journey of a thousand miles begins with a step. However, a journey started on a wrong footing may not end well. By implication, repeating a task a million times with expectation of a different result is tantamount to a fallacy. Little wonder that government, from one administration to another in Nigeria, has been insensitive to asking pertinent questions regarding the trajectory of finances made available and guaranteed to the agricultural sector. Indeed, the economy of scale and gains witnessed in the early beginnings of post-independence, which is anchored on products such as cocoa, palm oil, groundnut, rubber and other agricultural produce has not been re-examined in spite of continuous guaranteed finances made available (Okunlola \& Oke, 2018; Okunlola, 2013, 2014; Okunlola, Ogunbiyi, \& Oshi, 2009). In fact, finances guaranteed to these agricultural produce has more than tripled in the past decades. For instance, the value of finances guaranteed rose from 39 million, 63.7 million, 20.30 million, 480.9 million, 20,802.90 million, 3,297.40 and 1,358.80 in 
palm oil, rubber, cocoa, groundnut, poultry, cattle and roots and tubers, respectively, in 1981 to 116 million, 3.70, 578.50, 1,273.80, 1,698.20, 1559.70, 2,532.50, 14,412.90 in 1991. This amount oscillated among varying product in 2001. Specifically, cocoa guaranteed finance dropped to \# 435 million in 2000, but picked in 2001 to 1,579. This is also visible in rubber in 2004 where no fund was made available. Roots and tubers have also witnessed sufficient increase in guaranteed finance growing more than about 100 percent from between 1985 and 1986 at 2,180.20 million and $2,353.60$ million to about $13,494.10$ million in 1987 to 35,613 million in 1998 . There was an upsurge in the guaranteed finances to agriculture between 1999 and 2017 where roots and tubers moved from $57,920.50$ to $3,932,627.77$ and 2,406,835.38 in 2016 and 2017, respectively. This trajectory also permeates all other agricultural produce where guaranteed finances stood at 124,610 million, 160,295 million, 320,450, and 329,750 million for palm oil in 2016, 2017 and cocoa for the same period (CBN, 2018).

In spite of this tremendous guaranteed finances provision for agriculture in order to stimulate growth, Ayeomoni and Aladejana (2016), Ulimwengu, Collins, Yeboah, and Traub (2016), and Okunlola and Oke (2018) still observed saving, trade balance, and fiscal gaps in this regard. The country major earnings still lay on a mono product. A glimpse at economic growth rate as indicated by market prices reported by World Bank Indicator (WDI, 2018) has hovered around three (3) percent rate change, while agriculture as a percentage of gross domestic product (forestry and fishery value added) remains 20 percent between 2015 and 2017. Why is this so? And why has the government failed to look at the comparative cost advantage selected agricultural produce portends, spend less in this regard and seize the absolute advantage in the long run, in spite of administration changing hands more than fourteen times since independence? Without equivocation, it is in the interest of this study to objectively examine nominated agricultural products that can stimulate growth and that make the most contributory impact on the economy. Thus, we arrange this work in four main headings. Following the introduction is the literature review. This is followed by the methodology, results and findings, conclusion, and recommendations.

\section{LITERATURE REVIEW}

Olajide, Akinlabi, and Tijani (2011) carried out a study to analyze agricultural resource and economic growth in Nigeria. They found out that there exists a positive relationship between gross domestic product of Nigeria and its agricultural resources using ordinary least square (OLS). They posited that the agricultural sector was abandoned after the discovery of crude oil and government should provide adequate funding with infrastructural amenities such as electricity, good roads, etc. that would foster the free flow of agricultural products. Omankhanlen (2015) asserted that countries like Nigeria have not developed their agricultural sector to its full capacity because of her overdependence on imported goods. He further posited that the lack of agricultural credit to finance agrarian investment is a major problem in mechanizing our agricultural produce.

Oyakhilomen and Zibah (2014) examined agricultural production output and its effects on economic growth in Nigeria considering the ru- ral poverty alleviation. Where they used the autoregressive distributed lag (ARDL) bound test approach for their analysis. The result of their analysis showed that agricultural production significantly influenced economic growth positively in Nigeria. They further posited that irrespective of the economic growth, poverty is still on the increase. They recommended that the Nigerian economy should be diversified from being a mono-economy that depends majorly on crude oil to an agrarian-based economy, which would birth schemes to help alleviate poverty, especially at the grass root level. Ayeomoni and Aladejana (2016) asserted that the importance of the agricultural sector in a country cannot be overemphasized, because it has and will continue to be the source of feeding to the populace at large and also a veritable source of income to help economic development. Agriculture is the foundation of poverty alleviation, economic growth, and development, which makes the battle for a nations strategic economic growth to be either won or lost based on how it manages its agricultural sec- 
tor, hence, the more budgetary allocation should be made to the agricultural sector (Omorokunwa \& Obadiaru, 2016; Sertoğlu, Ugural, \& Bekun, 2017).

Ewetan, Fakile, Urhie, and Oduntan (2017) empirically examined the long-run relationship between agricultural output and economic growth in Nigeria using time series data from 1981 to 2014. They found from their co-integration test and vector error correction model (VECM) that there exists a long-run relationship between agricultural output and economic growth, which was in tandem with the result of the Granger causality test, indicating a causality between agricultural output and economic growth in Nigeria. They further stressed the importance of governmental funding, storage amenities and easy access to the agricultural products (good road networks) in order not to make the work too laborious so as to engender more participation in the sector. Banks are the key agents of fund disbursements to the agricultural sector, but some banks prefer lending funds based on the anticipated income of their customer's, especially when it has to do with micro lending (Godswill et al., 2018). This alone has discouraged banks (be it deposit money banks, microfinance banks, agricultural banks, etc.) from lending to small and peasant farmers who make up a large proportion of farmers in Nigeria.

\section{OTHER EMPIRICAL REVIEWS}

Authors in the literature are unanimous as to the fact that the agricultural sector portends the potential to solving the economic problems in the country. This is evident in the assumptions that most African countries, especially Nigeria, are endowed with abundant arable lands, weather and climatic condition that supports agriculture on a large scale. In fact, in the words of African Development Bank (AfDB, 2015, 2016, 2017, 2018), the agricultural sector accounts for thirty-two (32) percent of the continent's gross domestic product (GDP). Similarly, the sector is 2.5 percent times as effective at reducing poverty in Africa and indeed Nigeria as in other sectors (World Bank, 2016, 2017). In recognition of this fact, Nigeria past and present political administrations had put in place series of agricultural programs to help propel this growth aspiration.

Historically, the political administration of the country has changed hands more than thirteen times and has established one pilot program or the other that seek to how agricultural development in the country can be improved upon for ultimate economic benefits (Okunlola \& Oke, 2018; Ijaiya, Sanni, \& Amujo, 2016). Starting from the establishment of Nigeria Research Institute in 19601964, the Agricultural Research Council of Nigeria in 1971, National Accelerated Food Production Project (NAFPP), Integrated Agriculture Development Projects; Nigerian Agriculture and Cooperative Bank in 1973. Specialized Marketing Boards in 1975 to fix commodity prices and the establishment of The National Grains and Roots Cultivation in 1975 to accelerate production of grains and roots and crops in Nigeria. The Operation Feed the Nation (OFN) aimed at mobilizing members of the public to participate in agricultural production, River Basin Development Authorities in 1976; the Agriculture Credit Guarantee Scheme Fund (ACGSF) and Rural Banking Scheme in 1977. There is also the Land Reform of 1978 that seeks to make land available for agriculture purposes. We also have the Green Revolution Programme meant to increase agricultural produce; the Directorate for Foods, Roads and Rural Infrastructure (DEFRI) by the Babangida lead administration meant to promote rural development, which later merged with the Federal Ministry of Water Resources in 1993. There is the existence of Vision 20:20:20 and the NEEDS programs when the country returned to civil rule in 1999, the Maputo declaration of 2003 and the Economic Recovery Growth Plan (ERGP) of the present administration, which seek to diversify the economy with the mantra of agricultural economy (Okunlola \& Oke, 2018; Okunlola, 2014; Atagana \& Kalu, 2014; Okunlola et al., 2009; Fan, Omilola, \& Lambert, 2009; Akinboyo, 2008; Manyong, Ikpi, Olayemi, Yusuf, Omonona, \& Idachaba, 2003).

Isibor, Olokoyo, Arogundade, Osuma, and Ndigwe (2018) asserted that the agricultural sector was the pillar of the Nigerian economy before the discovery of oil in the early 1970's. From the year 2000 to 2007, agricultural sector in Nigerian contributed 7.4 per- 
cent (\%) to our GDP and it leapfrogged from 23.96 (\%) percent in the fourth quarter (Q4) of 2014 to 24.18 (\%) percent in the fourth month of 2016. In total but excluding amount set aside for the establishment of specialized agencies, projects, research, and other logistics, Nigeria government has guaranteed finance to nominated agricultural products examined in the study to the tune of 60,357,410.20 billion from 1981 to 2017. An amount incomparable to those allegedly starched abroad, stolen or misappropriated. In spite of this meager allocation, the country still keeps making provision to all available agricultural products in the country basket without proper anchoring on those with immediate benefit to the economy.

\section{SOME GROWTH MODELS}

There are an array of growth postulations, each with its proposition as to which best solves the problems at hand. Some of these models include:

1) Harrod - Domar growth model;

2) Kaldor growth model;

3) Solow growth model.

\subsection{Harrod - Domar growth model}

Economic growth models have been argued from the different postulations of growth theories. Each of these theories is associated with complexity in theory and practice (Okunlola, Ajala, \& Adesanya, 2015). For instance, Harrod - Domar model growth assumptions are summed up in dual nature of investment income and capital stock (Jhingan, 2012, 2007). Accordingly, where Domar opined that since investments (finance) generates income, on the one hand, and increases productive capacity, on the other hand, then, at what rate should investment increase in order to make the increase in income equal to the increase in productive capacity or in income (Ajide \& Eregha, 2015). Thus, to him, investment is a link between aggregate supply and demand. To Harrod, fundamental actual growth is represented by:

$$
G C=s,
$$

where $G$ is the rate of growth of output in a given period of time and can be expressed as $\Delta Y / Y ; C$ is the net addition to capital and is defined as the ratio of investment to the increase in income, i.e. $I / \Delta Y$, and $S$ is the average propensity to save, i.e. $S / Y$.

\subsection{Kaldor growth model}

Unlike Harrod - Domar, Kaldor model attempts to vary the savings-income assumption in the growth process (Jhigan, 2007). His assumption corroborates the classical thinking where savings is seen to equal the rate of profit of national income. Kaldor built his model on the following assumptions that:

1) there is a state of full employment so that total output or income is given;

2) national income or output consists of wages $(w)$ and profit $(p)$ only;

3) the marginal propensity to consume of a worker is greater than that of the capitalists whereby the marginal propensity to save of the workers $s w$ is small in relation to those of capitalist $s p$, i.e. $s p>s w$;

4) the investment-output ratio $(I / Y)$ is an independent variable;

5) the element of imperfect competition or monopoly power exists.

\subsection{Solow growth model}

Another key area of growth model is that of Solow postulation. Solow main divergent view in the growth process is the substitutability of capital and labor for continuous production, unlike that of Harrod - Domar, which assumes a fixed proportion in production (Jhigan, 2007). In Solow's argument, there are tendencies for the capital-labor ratio to adjust itself in the direction of equilibrium ratio in the long run. By implication, the output is the only commodity in an economy. Summarily, the model determines economic growth through the steady and positive increase in total production output of a nation. It assumes aggregate production output by three factors of labor, capital, and technology. It, however, emphasizes continuous change of technology as a link to increasing output, hence, his model is exogenous in nature (Okunlola \& Ogunbiyi, 2015). 


\section{METHODOLOGY}

To build a sustainable financing gap model and ensure optimal fund utilization of the agricultural sector for efficient, visible and impactful economic growth, the study uses the stepwise regression technique (forward analysis). Basically, stepwise regression allows for selection of variables out of several possible variables with the most contributory impact, leaving us with a most predictive model for our equation based on a criterion. That is, it allows for individual and joint comparison of variable that impact higher on the dependent variable. Unlike most studies like Ayeomoni and Aladejana (2016) using the regular ordinary least square estimates and emphasizing direct impact of selected variable, this study is unique in its own way by considering individually and jointly ranking of variables with most impactful effect. Here, growth is the dependent variable and proxied by gross domestic product. Agriculture is proxied by agricultural guaranteed credit (finance) to palm oil, cocoa, groundnuts, fishery, poultry, cattle, and roots and tubers. Data sets cover thirty-six (36) years and sourced from Central Bank of Nigeria statistical bulletin. The analysis is done using the Statistical Package for Social Sciences (SPSS v. 23).

\subsection{ACGSF period between 1981 and 1990}

During this period, amount guaranteed for palm oil average 20 percent of total in cocoa. In 1981, it was 39.0 million, 496.5 in 1982 and peak at $1,154.3$ and 2,724.5 in 1985 and 1986, respectively. It, however, nose dive to 175 million in 1990. This trend is also visible in all agricultural produce in the same period. Though, poultry roots and tubers and cattle have the highest receipt for same period. This is closely followed by fishery and groundnuts (CBN, 2018).

\subsection{ACGSF period between 1991 and 2000}

There is a great improvement in the agricultural credit guaranteed scheme funds (ACGSF) received in all segments of the agriculture in this era. What is likely responsible for this is possibly connected to the country's preparation for civil rule, which was later truncated in 1993. However, the eventual return in 1999 realigned commitment to improving agricultural practices as a means of diversifying the economy. Roots and tubers financing maintained its first position in the guaranteed fund with 294 million in total for the period. Followed by poultry with 89 million, cattle 44 million, fishery and groundnuts stood at 23 and 20 million, respectively (CBN, 2018).

\subsection{ACGSF period between 2001 and 2010}

This era witnessed several reforms in the financial sector leading to improved capacity, especially of the banking sector, at rendering increased intermediation function to the economy. Recall also that the economy newly realigned itself to a new way of democratic practices; whilst, the country became signatory to some declarations, especially that of Maputo, where ten (10) percentage of yearly budget is expected to be expanded to this sector to achieve overall economic growth (Okunlola \& Oke, 2018). Accordingly, a total of 12 million was received by roots and tubers, 4 million by poultry, fishery at 2 million; 1.1 million by cattle, followed by palm oil, cocoa and groundnuts at 4 million, 2 million and 08 million, respectively.

\subsection{ACGSF period between 2010 and 2018}

Roots and tubers continued to receive the larger share of agricultural guaranteed funding closely doubling it receipt at 23 million in this period. Poultry and fishery maintained second spot at 8 million, 3 million, respectively, while cocoa, cattle, palm oil and groundnut maintained fourth, fifth, sixth and seventh position, respectively (CBN, 2018). It is worthy of note that in spite of contribution of fishery in this regard, it is only 0.4 percent of the global production out of 14 percent of motorized and non-motorized distribution (Food and Agriculture Organization of the United Nations (FAO), 2018).

\section{MODEL SPECIFICATION}

The functional form for which the stepwise is built follows the econometrics basis given as: 
$Y=f\left(X_{1}, X_{2}, X_{3}, X_{4}, X_{5}, X_{6}, X_{7}\right) \cdot \mu$

when this is explicitly expressed, we have:

$G D P=f(A g C r O P, A g C r C o$, AgCrGrnt, AgCrfshry, AgCrPltry, $\mathrm{AgCrCtl}, \mathrm{AgCrRt})$.

If eq. (2) is expressed in its linear form, we have:

$G D P=\beta_{0}+\beta_{1} A g f i n O P+\beta_{2} A g f i n C o+$

$+\beta_{3}$ AgfinGrnt $+\beta_{4}$ Agfinfshry +

$+\beta_{5}$ AgfinPltry $+\beta_{6}$ AgfinCtl $+\beta_{7}$ AgfinRt,

where $A g f i n O P$ - agricultural finance to palm oil, AgfinCo - agricultural finance to cocoa, AgfinGrnt - agricultural finance to groundnut, Agfinfshry - agricultural finance to fishery, AgfinPltry - agricultural finance to poultry, AgfinCtl - agricultural finance cattle, AgfinRt - agricultural finance roots and tubers, $\alpha$ - the intercept, $\beta_{1}, \beta_{2}, \beta_{3}, \beta_{4}, \beta_{5}, \beta_{6}, \beta_{7}$ - the regression coefficients of Agfin and GDP, $u_{t}$ an error term.

Based on stepwise regression that allows series of steps to be performed that leads to parsimony where a fewer number of parameters are left for estimation based on beta coefficient with the highest $t$ value (but with a caveat).

Thus, eq. (3) becomes:

$$
Y=\beta_{0}+\beta_{1} X_{n}
$$

where $X_{1}, X_{2}, X_{3}, X_{4}, X_{5}, X_{6}, X_{7}$ are independent variables as in $\mathrm{AgfinOP}$ above.

\section{RESULTS AND FINDINGS}

Table 1. Summary of results based on step 1: $Y=\beta_{0}+\beta_{1} X$ ?

Source: SPSS output 2018, version 23.

\begin{tabular}{c|c:c:c:c:c:c:c}
\hline \multicolumn{1}{c}{$\boldsymbol{Y}$} & $\boldsymbol{X}_{\mathbf{1}}$ & $\boldsymbol{X}_{\mathbf{2}}$ & $\boldsymbol{X}_{\mathbf{3}}$ & $\boldsymbol{X}_{\mathbf{4}}$ & $\boldsymbol{X}_{\mathbf{5}}$ & $\boldsymbol{X}_{\mathbf{6}}$ & $\boldsymbol{X}_{\mathbf{7}}$ \\
\hline$\beta_{1}$ & .832 & .870 & 1.087 & .807 & .830 & .502 & .898 \\
\hline$t$-stats & 8.856 & 10.419 & 3.967 & 8.086 & 8.797 & 3.436 & 12.100 \\
\hline$p$-value & .000 & .000 & .000 & .000 & .000 & .002 & .000 \\
\hline
\end{tabular}

$\mathrm{Ab}$ initio, the variable with most useful prediction using the $t$-stats from the table is $X_{7}$ (roots and tubers AgfinRt), having the highest $t$-value $=12.100$ with a sig value $=0.000$. Thus, this variable is retained in the model as specified by stepwise regression. As a result, the variable in the model at first run is $Y=\beta_{0}+\beta_{1} X_{7}$ and it is retained until all variables are selected in the model.

Table 2. Summary of results based on step 2: $Y=\beta_{0}+\beta_{1} X_{7}+\beta_{2} X$ ?

Source: SPSS output, 2018, version 23

\begin{tabular}{l|l|l|l|l|l|l}
\hline \multicolumn{1}{c}{$\mathbf{Y}$} & $X_{\mathbf{7}}+X_{\mathbf{1}}$ & $X_{\mathbf{7}}+X_{\mathbf{2}}$ & $X_{\mathbf{7}}+X_{\mathbf{3}}$ & $\boldsymbol{X}_{\mathbf{7}}+X_{\mathbf{4}}$ & $X_{\mathbf{7}}+X_{\mathbf{5}}$ & $X_{\mathbf{7}}+X_{\mathbf{6}}$ \\
\hline$\beta_{1}$ & .236 & .433 & .096 & .168 & 1.28 & .009 \\
\hline$t$-stats & 1.688 & 4.608 & 1.086 & 1.222 & .762 & .100 \\
\hline$p$-value & .101 & .000 & .285 & .230 & .451 & .921 \\
\hline
\end{tabular}

Having retained $X_{7}$ (roots and tubers) in the model, based on Table 1, the beta value with most highest $t$-stats value in Table 2 is in $X_{7}+X_{2}=4.608$ column and it is significant with $p$-value at $=0.000$, thus, retained in the model. By implication, roots and tubers and cocoa are left in the model.

Table 3. Summary of results based on step 3: $Y=\beta_{0}+\beta_{1} X_{7}+\beta_{2} X_{2}+\beta_{3} X$ ?

Source: SPSS output, 2018, version 23

\begin{tabular}{|c|c|c|c|c|c|}
\hline $\mathbf{Y}$ & $X_{7}+X_{2}+X$ & $\gamma_{7}+X_{2}+X_{3}$ & $X_{7}+X_{2}+X_{4}$ & $X_{7}+X_{2}+X_{5}$ & $X_{7}+X_{2}+X_{6}$ \\
\hline$\beta_{1}$ & .129 & .026 & .182 & .344 & .164 \\
\hline$t$-stats & 1.112 & .362 & 1.691 & 2.685 & 2.249 \\
\hline$p$-value & .274 & .720 & .100 & .011 & .031 \\
\hline
\end{tabular}

Again, result of Table 3 shows that the variable beta coefficient with $X_{5}$ has the highest $t$-stats value $=2.685$, thus, it is selected and retained in the model. That is, $X_{7}+X_{2}+X_{5}$ roots and tubers, cocoa and poultry have the chance of being selected from the numerous variables specified as that with most contributory impact for stepwise analysis, but not without a caveat.

Thus, from the result, the following model is specified:

$$
Y=\beta_{0}+\beta_{1} X_{7}+\beta_{2} X_{2}+\beta_{3} X_{5}+u_{t} \text {. }
$$


Table 4. Model summary

Source: SPSS output, 2018, version 23.

\begin{tabular}{|c|c|c|c|c|c|c|c|c|c|c|}
\hline \multicolumn{11}{|c|}{ Model summary } \\
\hline \multirow[b]{2}{*}{ Model } & \multirow[b]{2}{*}{$\mathbf{R}$} & \multirow[b]{2}{*}{$R$ Square } & \multirow{2}{*}{$\begin{array}{l}\text { Adjusted } \\
R \text { Square }\end{array}$} & \multirow{2}{*}{$\begin{array}{l}\text { Std. error } \\
\text { of the estimate }\end{array}$} & \multicolumn{5}{|c|}{ Change statistics } & \multirow{2}{*}{$\begin{array}{l}\text { Durbin- } \\
\text { Watson }\end{array}$} \\
\hline & & & & & $\begin{array}{c}R \text { Square } \\
\text { change }\end{array}$ & F Change & df1 & df2 & $\begin{array}{c}\text { Sig. } \\
\text { F Change }\end{array}$ & \\
\hline 1 & $.898^{a}$ & .807 & .802 & 15246.91094 & .807 & 146.407 & 1 & 35 & .000 & \\
\hline 2 & $.939^{\mathrm{b}}$ & .881 & .874 & 12137.47412 & .074 & 21.230 & 1 & 34 & .000 & \\
\hline 3 & $.950^{\circ}$ & .903 & .894 & 11161.06839 & .021 & 7.209 & 1 & 33 & .011 & \\
\hline 4 & $.948^{d}$ & .898 & .892 & 11242.09287 & -.004 & 1.495 & 1 & 33 & .230 & 2.119 \\
\hline
\end{tabular}

Note: a. Predictors: (constant), RT, b. Predictors: (constant), RT, Cocoa, c. Predictors: (constant), RT, Cocoa, Poultry, d. Predictors: (constant), Cocoa, Poultry, e. Dependent variable: GDP.

After careful selection of the most parsimony variables that formed the basis for a plausible financing gap model in the equation, the researcher examined the level of their contributions and, the stepwise result is shown in the above table. The $R$ Squared, which explains the variability of a predictor to a dependent variable and as reported individually and collectively shows that roots and tubers (a) contribution to gross domestic product is 80 percent. As such, for anyone percent change in the financing required, there will be a corresponding 81 percent change in the gross domestic product. Similarly, the combination of roots and tubers and cocoa (b) shows that they jointly contribute 87 percent to gross domestic product in the country.
Also, roots and tubers, cocoa and poultry (c) jointly contribute about 89 percent variability to gross domestic product. In the final model, (d) financing cocoa and poultry will bring about 90 percent of variability to gross domestic product in Nigeria. Further, the $D W=2.1$ and fulfill the rule of thumb. By implication, the result is a pointer that rather than be master of all, the government can finance those agricultural productions with most impactful or contribution to the growth of the economy. If examined deeply, the value chain of selected agricultural product in the model cannot be overemphasized. These products serve as raw material, as well as the ready-to-use product. For other results of the study please see Appendix A and B.

\section{CONCLUSION AND RECOMMENDATIONS}

This work has provoked a pertinent question as to whether Nigeria's economy can be stimulated by agriculture vis-à-vis the financing gap through formulating a better model at arriving at the best judgment. So far, it took a paradigm shift from the norm of regular regression by examining agricultural finance with the most contributory impact on the economy using the stepwise technique. Stepwise does not give priority to any order of entering variable into the system. What it simply does is to take variable as they become most impactful individually and jointly step by step (i.e. first entered variable might be first or least impactful). From the result, order of entering was palm oil, cocoa, groundnuts, fishery, poultry, cattle and roots and tubers. On individual contributory power to economic growth from the result, agricultural credit guaranteed finance to roots and tubers is first, contributing 81 percent total variability to the economic growth, hence, it is ranked first. Cocoa and poultry jointly followed at 88 percent and 90 percent, respectively. However, combination of cocoa and poultry only stood at 89 percent. By implication and as shown by the result, roots and tubers only are most impactful on economic growth.

Worthy of note is that agricultural practices in the country is barely commercialized (until the recent mantra by the new administration), nor mechanized. Technological innovations adoption is also non-existence. The Maputo declaration since 2003 of allocating 10 percent year-in-year country budget is faintly realized; whilst, the dawn of the new Economic Recovery Growth Plan (ERGP) is yet to usher in expected value result. Agricultural small and medium scale enterprises and allied business are not adequately encouraged and, as such, full potential is optimally aloof. 
Based on the findings, it is clear that government must as a matter of responsibility, accountability and not being wasteful stop the financing of agricultural product with little or less impact on the economy. They should as a matter of urgency look to prioritizing finance to agricultural products with the most contributory impact on growth in other to attain desired growth in the sector and ultimately the economy. Indeed, the model proffers a comparative cost advantage as the way to go. Based on the reviewed literatures also, it can be deduced that there is a need for the sectoral allocation of loans to be strictly adhered to by deposit money banks and the central banks should sanction defaulting banks. This is because most deposit money banks see the agricultural sector as not being lucrative due to its seasonal nature of returns, some has even imposed high and/or exorbitant interest rates all the a quest to discourage farmers from accessing such loans. These has made such deposit money banks to finance the so-called lucrative and performing sectors in the economy at the expense of the agricultural sector by granting minimum interest rate so as to encourage more borrowings from them. These act has impeded the access to finance by the agricultural sector especially the small and peasant farmers. Thus, the Central Bank should monitor its sectoral guidelines and limits for lending to the various sectors in the economy to ensure compliance and further analytical techniques can be used to empirically examine same areas with additional variables.

\section{ACKNOWLEDGEMENT}

The authors wish to appreciate Covenant University Management for providing the article processing charge of this manuscript.

\section{REFERENCES}

1. Africa Development Bank (2015). African Agricultural Report 2016: The Maputo Commitments and the 2014 African Union year of Agriculture. (AfDB) Group, Tunis, Tunisia. Retrieved from www.afdb. org

2. Africa Development Bank (2016). African Agricultural Report 2016: Progress towards agricultural transformation. (AfDB) Group, Tunis, Tunisia. Retrieved from www.afdb.org

3. Africa Development Bank (AfDB) (2018). Africa's Economic Outlook: Africa's Macroeconomic performance and prospects. (AfDB) Group, Tunis, Tunisia. Retrieved from www.afdb.org

4. African Development Bank (AfDB) (2017). Entrepreneurship and Industrialization: African Economic Outlook 2017. Abidjan, Cote d'Ivoire. Retrieved from www.afdb.org

5. Ajide, K. B., \& Eregha, P. B. (2015). Foreign direct investment, economic Freedom and economic
Performance in Sub-Saharan Africa. Managing Global Transition, 13(1), 43-57. Retrieved from https://econpapers.repec.org/ article/mgtyoumgt/v_3a13_3ay_3 a2015_3ai_3a1_3ap_3a43-57.htm

6. Ayeomoni, I. O., \& Aladejana, S. A. (2016). Agricultural Credit and Economic Growth Nexus. Evidence from Nigeria. International Journal of Academic Research in Accounting, Finance, and Management, 6(2), 146-158. http://dx.doi.org/10.6007/IJARAFMS/v6-i2/2099

7. Central Bank of Nigeria (CBN) (2018). CBN statistical bulletin. Retrieved from https://www.cbn. gov.ng/documents/Statbulletin.asp

8. Ewetan, O., Fakile, A., Urhie, E., \& Oduntan, E. (2017). Agricultural Output and Economic Growth in Nigeria. Journal of African Research in Business \& Technology. https://doi. org/10.5171/2017.516093

9. Fan, S., Omilola, B., \& Lambert, M. (2009, April). Public spending for
Agriculture in Africa: Trends and Composition (ReSAKSS Working Paper No. 28). Retrieved from https://www.researchgate.net/ publication/265072698_Public_ Spending_for_Agriculture_in_Africa_Trends_and_Composition

10. Food and Agriculture Organization of United Nations [FAO] (2018). The state of World fisheries and aquaculture: Meeting the sustainable development goals. Retrieved from https://knowledge4food.net/knowledge-portal-item/ the-state-of-world-fisheries-andaquaculture-2018/

11. Godswill, O., Ailemen, I., Osabohien, R., Chisom, N., \& Pascal, N. (2018). Working capital management and bank performance: empirical research of ten deposit money banks in Nigeria. Banks and Bank Systems, 13(2), 49-61. https://doi. org/10.21511/bbs.13(2).2018.05

12. Ijaiya, M. A., Sanni, M., \& Amujo, E. T. (2016). Agricultural credit guarantee scheme fund: Tool for Economic growth in Nigeria. 
Osogbo Journal of Management, 1(3), 20-33.

13. Isibor, A., Olokoyo, F., Arogundade, M., Osuma, G., \& Ndigwe, C. (2018). Exchange Rate Management and Sectoral Output Performance. International journal of supply chain management, 7(5), 129-134. Retrieved from https:// ojs.excelingtech.co.uk/index.php/ IJSCM/article/view/2029

14. Jhigan, M. L. (2012). Principles of Economics (4th ed.). Delhi: Vrinda.

15. Jhigan, M. L. (2007). MacroEconomic Theory (11th ed.). Delhi: Vrinda.

16. Manyong, V. M., Ikpi, A., Olayemi, J. K., Yusuf, S. A., Omonona, R., \& Idachaba, F. S. (2003). Agriculture in Nigeria: Identifying Opportunities for Increased Commercialization and Investment. USAID/Nigeria Main report from International Institute of Tropical Agriculture (IITA) and University of Ibadan. Retrieved from https://cgspace.cgiar.org/ handle/10568/91838

17. Okunlola, F. A. (2013). Public Sector Investment in Agriculture: Structure and Influence on Nigerian Economy (1970-2010). An MBA Thesis submitted to the Department of Finance and Banking, University of Port Harcourt.

18. Okunlola, F. A. (2014). NEXIM Bank and Export Promotion: Theory and Evidence. An M.SC thesis submitted to the
Department of Finance and Banking. University of Port Harcourt.

19. Okunlola, F. A., \& Oke, J. A. (2018). Agricultural Finance, Agriculture Value Added and Diversification Growth Panacea: An Economy Comparison. Peer Review Proceeding 4th Annual International Academic Conference on Accounting and Finance organized by The Institute of Chartered Accountants of Nigeria up-coming at Covenant University on April 18-20, 2018.

20. Okunlola, F. A., Ajala, A. O., \& Odesaya, T. A. (2015) Infrastructure dilemma and alternative funding: Evidence from Nigeria. Advances in Multidisciplinary and Scientific Research Journal, 12, 10-17.

21. Okunlola, F. A., Ogunbiyi, S. S., \& Oshi, J. E. O. (2010). Government expenditure on agriculture and the Nigerian Economy (19702009). The Nigerian Journal of Financial Research, 1(2), 172-189.

22. Olajide, O. T., Akinlabi, B. H., \& Tijani, A. A. (2011). Agriculture Resource and Economic Growth in Nigeria. European Scientific Journal, 8(22), 103-115. Retrieved from https://eujournal.org/index. php/esj/article/view/422

23. Omankhanlen, A. E. (2015). Agricultural Investment Risk Relationship to National Domestic Production. Banking, Finance, and Accounting:
Concepts, Methodologies, Tools, and Applications Information Resources Management Association USA, 1-3, 19. https:// doi.org/10.4018/978-1-46666268-1.ch033

24. Oyakhilomen, O., \& Zibah, R. G. (2014). Agricultural Production and Economic Growth in Nigeria: Implication for Rural Poverty Alleviation. Quarterly Journal of International Agriculture, 54(3), 207-223. Retrieved from https://ideas.repec.org/a/ags/qjiage/195735.html

25. Sertoğlu, K., Ugural, U., \& Bekun, F. V. (2017). The Contribution of Agricultural Sector on Economic Growth of Nigeria. International Journal of Economics and Financial Issues, 7(1), 547-552. Retrieved from https://www. econjournals.com/index.php/ijefi/ article/view/3941

26. Ulimwengu, J., Collins, J., Yeboah, F., \& Traub, L. N. (2016). Driving economic transformation Africa (Agriculture status report 2016: Progress towards Agricultural Transformation in Africa). Retrieved from http://www.ifpri. org/publication/driving-economic-transformation

27. World Bank (2016). World Development Indicators. Washington, DC: The World Bank.

28. World Bank (2017). Doing Business 2018: Reforming to Create Jobs. Washington, DC: The World Bank. 


\section{APPENDIX A}

Table A1. ANOVA

Source: Authors' computation from SPSS output.

\begin{tabular}{|c|c|c|c|c|c|c|}
\hline \multicolumn{7}{|c|}{ ANOVA $^{a}$} \\
\hline & Model & Sum of squares & df & Mean square & $\mathbf{F}$ & Sig. \\
\hline \multirow{3}{*}{1} & Regression & 34034897699.528 & 1 & 34034897699.528 & 146.407 & $.000^{\mathrm{b}}$ \\
\hline & Residual & 8136390267.228 & 35 & 232468293.349 & - & - \\
\hline & Total & 42171287966.757 & 36 & - & - & - \\
\hline \multirow{3}{*}{2} & Regression & 37162466516.486 & 2 & 18581233258.243 & 126.130 & $.000^{\circ}$ \\
\hline & Residual & 5008821450.271 & 34 & 147318277.949 & - & - \\
\hline & Total & 42171287966.757 & 36 & - & - & - \\
\hline \multirow{3}{*}{3} & Regression & 38060496197.458 & 3 & 12686832065.819 & 101.845 & $.000^{\circ}$ \\
\hline & Residual & 4110791769.299 & 33 & 124569447.555 & - & - \\
\hline & Total & 42171287966.757 & 36 & - & - & - \\
\hline \multirow{3}{*}{4} & Regression & 37874209794.991 & 2 & 18937104897.495 & 149.837 & $.000^{\mathrm{e}}$ \\
\hline & Residual & 4297078171.766 & 34 & 126384652.111 & - & - \\
\hline & Total & 42171287966.757 & 36 & - & - & - \\
\hline
\end{tabular}

Note: a. Dependent variable: GDP, b. Predictors: (constant), RT, c. Predictors: (constant), RT, Cocoa, d. Predictors: (constant), RT, Cocoa, Poultry, e. Predictors: (constant), Cocoa, Poultry.

\section{APPENDIX B}

Table B1. Coefficients

Source: Authors' computation 2018 from SPSS output.

\begin{tabular}{|c|c|c|c|c|c|c|}
\hline \multicolumn{7}{|c|}{ Coefficients $^{a}$} \\
\hline & \multirow{2}{*}{$\underset{B}{\text { Model }}$} & \multicolumn{2}{|c|}{ Unstandardized coefficients } & \multirow[t]{2}{*}{$\begin{array}{c}\text { Standardized } \\
\text { coefficients }\end{array}$} & \multirow[t]{2}{*}{$\mathbf{t}$} & \multirow[t]{2}{*}{ Sig. } \\
\hline & & Std. error & Beta & & & \\
\hline \multirow{2}{*}{1} & (Constant) & 1220.563 & 3070.688 & - & .397 & .693 \\
\hline & $R T$ & .022 & .002 & .898 & 12.100 & .000 \\
\hline \multirow{3}{*}{2} & (Constant) & 2281.192 & 2455.270 & - & .929 & .359 \\
\hline & $\mathrm{RT}$ & .014 & .002 & .562 & 5.983 & .000 \\
\hline & Cocoa & .164 & .035 & .433 & 4.608 & .000 \\
\hline \multirow{4}{*}{3} & (Constant) & 1889.954 & 2262.452 & - & .835 & .410 \\
\hline & RT & .005 & .004 & .197 & 1.223 & .230 \\
\hline & Cocoa & .191 & .034 & .506 & 5.587 & .000 \\
\hline & Poultry & .023 & .008 & .344 & 2.685 & .011 \\
\hline \multirow{3}{*}{4} & (Constant) & 2383.220 & 2242.366 & - & 1.063 & .295 \\
\hline & Cocoa & .219 & .026 & .578 & 8.362 & .000 \\
\hline & Poultry & .031 & .005 & .476 & 6.882 & .000 \\
\hline
\end{tabular}

Note: a. Dependent variable: GDP. 